Am. Midl. Nat. 153:321-326

\title{
Abundance of Green Tree Frogs and Insects in Artificial Canopy Gaps in a Bottomland Hardwood Forest
}

\author{
SCOTT HORN ${ }^{1}$, JAMES L. HANULA, MICHAEL D. ULYSHEN \\ USDA Forest Service, 320 Creen Street, Athens, Georgia 30602 \\ $\triangle N D$ JOHN C. KILGO \\ USDA Forest Service-Savannah Ritwer, P.O. Box 700, New Ellenton, South Carolina 29809
}

\begin{abstract}
We found more green tree frogs (Hyla cinerea) in canopy gaps than in closed canopy forest. Of the 831 green tree frogs observed, $88 \%$ were in canopy gaps. Likewise, higher numbers and biomasses of insccts were captured in the open gap habitat. Flies were the most commonly collected insect group accounting for $54 \%$ of the total capture. These data suggest that one reason green tree frogs were more abundant in canopy gaps was the increased availability of prey and that small canopy gaps provide early successional habitats that are beneficial to green tree frog populations.
\end{abstract}

\section{INTRODUCTION}

Southeastern bottomland forests serve as an important source of hardwood timber, as well as critical habitat for many wildlife species. Land-clearing for agriculture since the colonization of North America has resulted in a large reduction of these wetland habitats (Dahl, 1990) and current projections estimate that, by the year 2030, hardwood timber removal will increase by $64 \%$ over 1984 levels (USDA Forest Service, 1988). Therefore, it is imperative to understand these ecosystems and to develop sustainable practices that retain the full complement of species associated with bottomland hardwoods while still generating timber revenue. Gurrently, clearcutting is the most common method of harvesting and regenerating bottomland forests (Clatterbuck and Meadows, 1993). It remains a valuable silvicultural practice for efficient removal of trees and provides habitat for many early successional wildlife species (Costello et al, 2000). Despite the benefits of this even-aged method, public concerns have risen about the use of clearcutting (Guldin, 1996), so al ternatives are needed.

Group-selection harvesting is an uneven-aged method used to mimic small-scale disturbances within forests. This practice may be advantageous in an ecosystem management approach (Guldin, 1996). These smaller disturbances are thought to encourage species diversity by increasing sunlight, minimizing competitive exclusion and creating habitat heterogeneity (Connell, 1978; Hartshorn, 1978; Denslow, 1980; Uhl and Murphy, 1981; Sousa, 1984; Brokaw, 1985; Shure and Phillips, 1991). Changes in plant diversity and abundance are followed by corresponding changes in insect communities (Gorham et al., 1996; Waltz and Whitham, 1997). For example, Walters and Stiles (1996) found pollinator visitation rates were greater in forest canopy gaps compared to surrounding closed canopy forests. Similarly, studies have shown carabid beetle diversity and abundance increased in disturbed areas (Thompson and Allen, 1993; Beaudry et al., 1997; Heliola et al., 200I; Koivula et al., 2002; Warriner et al., 2002).

Like arthropods, many vertebrates are known to take advantage of the resources available in newly created canopy gaps. Several studies have noted certain species of birds use canopy gaps, both natural (Wilson et al, 1982; Blake and Hoppes, 1986; Martin and Karr, 1986; Schemske and Brokaw, I981; Wunderle et al., 1987; Levey, 1988) and artificial (Kilgo et al,

${ }^{1}$ Corresponding author e-mail: (shorn01@fs.fed.us) 
1999; Moorman and Guynn, 2001), more than closed canopy forest. It is likely that populations of reptiles and amphibians are affected by group-selection harvests as well. Amphibians are an important part of most southeastern communities (Bennett et al., 1980) and are widely considered to be good indicators of environmental health and function (Phelps and lancia, I995). Because of their importance within ecosystems, several studies have sought to determine how forest management affects their populations. Clearcutting is a major factor altering herpetofaunal communities (Enge and Marion, 1986; Pough et al, 1987; Petranka et al, 1998; Phelps and Lancia, 1995), but Greenberg (2001) found that gaps created by wind disturbance in the southern Appalachians had litle effect on terrestrial amphibian abundance relative to the surrounding intact forest.

Few studies have examined how forest management affects species such as the green tree frog ( $H y l a$ cinerea) that spend litle time on the ground. In one study, Phelps and Lancia (1995) captured green tree frogs more frequently in clearcuts using the pipe collection method, but they were uncertain if their resul's were due to their method of trapping or to habitat preference. Likewise, Cromer et al (2002) documented that tree frog abundance was positively associated with the creation of artificial canopy gaps.

Terrestrial arthropods serve as food for many amphibian and reptile species, but little information exists on the potential interactions among forest management, arthropods and hylid tree frogs. The objectives of this study were to compare the abundance of green tree frogs in artificially created canopy gaps to that at similar heights in the surrounding closed canopy forest and to compare frog abundance with arthropod abundance in the same habitats.

\section{Methons}

This study was conducted in 2003 at the U. S. Department of Energy (DOE), Savannah Riwer Site (SRS) near Aiken, South Carolina. The SRS is an 80,269 ha nuclear production facility located in the upper Atlantic Coastal Plain Physiographic Prownce (Knox and Sharitz, 1990). The majority of the land on the site is forested and managed as a DOE National Environmental Research Park. The stands used in this study consisted of 75 yearold bottomland hardwoods approximately 120 ha in total size (Kilgo, 1997). Common overstory trees within the intact forest included bald cypress (Taxodium distichum), laurcl oak (Quercus laurifolia), willow oak ( $Q$, phellos), overcup oak (Q. brata), cherrybark oak $(Q$ falata var pagodaefolia), swamp chestnut oak ( $Q$ michauxiz), sweetgum (Liquidambar styracifua), red maple (Acer rubrum) and loblolly pine (Pinus taeda). The midstory consisted of red mulberry (Morus rubra), ironwood (Carpinus caroliniana) and American holly (llex opaca), while the understory was dominated by dwarf palmetto (Sabal minor) and switchcane (Anudinaria gigantea). Pre-harvest basaI area of the forest was $33 \mathrm{~m}^{2} /$ ha (Pauley et al, 1996). Artificial canopy gaps were created by group selection harvests in August 2000 . We sampled 0.50 and 0.26 ha gaps that consisted mainly of dwaxf palmetto, switchcane, blackberries (Rubus spp.), sweetgum and plume grass (Enianthus giganteus). Due to the large amount of rainfall received in 2003, the gaps and surrounding forest were flooded throughout most of the year and were covered with approximately $15 \mathrm{~cm}$ of water when frog observations were made.

Green tree frog abundance was recorded in five canopy gap plots and five closed canopy forest plots in August and September 2003. Three of the canopy gap plots were 0.26 ha in size, while two were 0.50 ha in size. The area searched in the corresponding closed canopy forest plots was similar in size to that of the created gap and were selected randomly. The distance between plots varied, however the minimum distance between canopy gaps was approximately $200 \mathrm{~m}$. Each plot was searched for 1 man-hour and all tree frogs encountered during that time were counted. Forest interior plots consisted of areas similar in size to the 
canopy gaps located approximately $50 \mathrm{~m}$ from each gap. Vegetation in the gaps was $1-3 \mathrm{~m}$ tall so we only searched vegetation in the forest interior that was in the same size range.

Active-flying arthropods were sampled in 2001 using modified malaise traps (Canopy Traps, Sante Traps Inc, Lexington, Kentucky). The traps were $2.5 \mathrm{~m}$ in height with collection containers at the top and bottom. Each trap had a central cross-shaped barrier which allowed insects to enter from any direction. Arthropods entering the traps were collected in plastic bottles containing a NaCl and 1\% formaldehyde solution in which a drop of detergent was added to reduce surface tension. Samples were retarned to the laboratory and stored in $70 \%$ alcohol until they could be identified. Traps were operated for one 7 $\mathrm{d}$ period in the months of April, May, July and November 2001. Although we collected insect data 2 y before the frog surveys, it is likely that relative insect abundance between gap and forest habitat was similar in 2001 and 2003 . The reason for this assumption is because the gaps were similar in their plant composition in $200 \mathrm{f}$ and 2003 , with the main difference being plant height, while the forest plots were unchanged between years.

Arthropods were identified to order, oven-dried for $48 \mathrm{~h}$ at $40 \mathrm{C}$, and weighed to estimate biomass. A paired t-test was used to determine if the numbers of insects or tree frogs differed between gap and forest plots.

\section{REsults and Discussion}

Of 331 green tree frogs observed, more were found in the gaps (mean $\pm \mathrm{sE}=58.4 \pm 18.5$ ) compared to closed canopy forest (mean $\pm \mathrm{sE}=7.8 \pm 2.5)(\mathrm{P}=0.027)$. Greater than $88 \%$ of the total number of frogs observed were in gaps where they occurred on dwarf palmetto, switchcane, plume grass and sedges while frogs in the forest interior were almost exclusively on dwarf palmetto. This may be attributed to dwarf palmetto being the dominant understory plant present in closed canopy forests. Only $2.4 \%$ of the frogs observed were adults. We collected 7628 insects from the 10 plots, with significantly higher numbers $(P=0.009)$ collected from canopy gaps than from the forest interior (Table 1). Greater than $86 \%$ of the Insects captured and $82 \%$ of the biomass were from artificially created canopy gaps. Diptera, Lepidoptera, Coleoptera and Hymenoptera, made up $>75 \%$ and $80 \%$ of the total number of insects and biomass, respectively. In general, the mean number of each insect order captured was higher in canopy gaps (Table 1) than in forests, but Diptera $(\mathrm{P}=0.014)$, Hymenoptera ( $\mathrm{P}=0.0 \mathrm{1} 5$ ), and Coleoptera $(\mathrm{P}=0.080$ ) were significantly more abundant in gaps and Lepidotera biomass (mainly moths) was higher in gaps ( $\mathbf{P}=0.025$ ).

The plant community response to disturbance influences many aspects of the ecosystem (Runkle, I998), and is particularly important in determining the insect community's diversity and distribution (Waltz and Whitman, 1997). The gaps created in this study had an abundance of early-successional vegetation and were dramatically different than the undisturbed forest. The herbaceous vegetation in the gaps was more structurally complex compared to the closed canopy forest (personal observation) and this may explain why we saw increases in insect abundance.

Hylid tree frogs are generally considered to be indiscriminate predators (Oplinger, 1976; Clark, 1974; Johnson and Christiansen, 1976; Labanick, 1976; Tyler and Hoestenbach, 1979). Holbrook (1842) stated that green tree frogs fed on flies and Haber (1926) found them to commonly prey upon flies, beetles, ants and moths. Freed (1982) used stomach pumping to show that larval moths and beetles were the two most common prey selected in the field, while laboratory studies proved that flies in the genus Musca were preferred over other available prey. Taken together, these studies suggest that the availability and abundance of various prey types determine the diet of green tree frogs, not preference for a particular type or species (Oplinger, 1967; Johnson and Christiansen, 1976; Labanick, 1976). 
TABLE 1, - Mean number and biomass $(\mathrm{g})$ of the four most abundant orders of insects collected and the mean number of insects captured per plot in canopy gaps $(n=5)$ and interior bottomland hardwood forest $(\mathbf{n}=\mathbf{5})$

\begin{tabular}{|c|c|c|c|c|}
\hline \multirow[b]{2}{*}{ Order } & \multicolumn{2}{|c|}{ Gap } & \multicolumn{2}{|c|}{ Forest } \\
\hline & Mear No. $\pm \mathrm{sE}$ & Mean WL $\pm \mathrm{si}$ & $\operatorname{Mean} \mathrm{No} . \pm \mathrm{sr}$ & Mean $W_{\mathrm{L}} \pm \mathrm{si}$ \\
\hline Diptera & $768.2 \pm 226.5^{*: *}$ & $0.24 \pm 0.094$ & $54.4 \pm 12.9$ & $0.15 \pm 0.07$ \\
\hline Lepidoptera & $106.8 \pm 21.7$ & $0.21 \pm 0.060^{\mathrm{s}}$ & $63.0 \pm 16.3$ & $0.02 \pm 0.01$ \\
\hline Coleoptera & $85.6 \pm 23.7^{*}$ & $0.39 \pm 0.19^{*}$ & $37.0 \pm 6.2$ & $0.07 \pm 0.02$ \\
\hline Hymenoptera & $45.6 \pm 9.2^{*-*}$ & $0.13 \pm 0.054^{*}$ & $15.0 \pm 3.9$ & $0.03 \pm 0.02$ \\
\hline Mean (all orders) & $1121 \pm 266.5^{* * k}$ & $1.26 \pm 0.51 \%$ & $204.6 \pm 31.6$ & $0.26 \pm 0.09$ \\
\hline
\end{tabular}

*denotes a significant difference $(\mathrm{P}<0.10)$

$*$ denotes a significant difference $(P<0,05)$ between gap and forest based on a paired $t$-test

The distribution and abundance of food is one of the most important factors influencing the evolution of adaptations among species (Krebs and Davies, 1987). Studies have suggested that increased food resources are correlated with higher densities of birds (Blake and Hoppes, 1986). However, little or no information exists on how amphibians, particularly hylid tree frogs, respond to increased food availability. It seems that locally abundant food would influence the distribution and abundance of green tree frogs. Our study shows that green tree frogs were more abundant in gaps where they had five to six times more food available compared to forested plots located only $50 \mathrm{~m}$ away.

Presently, clearcuting is the most common method for regenerating bottomland hardwoods and provides habitat for opportunistic species that respond well to ephemeral habitats (Costello et al, 2000). However, some species only remain if certain attributes are recained in the surrounding forest, as in group-selection harvests. Cromer et al. (2002) found that gap creation likely benefits some groups like tree frogs, while reducing the suitability of habitat for others like salamanders. Phelps and Lancia (1995) and Enge and Marion (1986) concluded that smaller forest clearings would benefit the diversity of local herpetofauna. Small-scale disturbances such as canopy gaps provide low growing vegetative structure for insects and green tree frogs, while leaving the surrounding forest uncompromised. Bury and Gorn (1988) found reptiles to be more common in clearcuts due to an increase in ambient temperature, a finding similar to that of Phelps and Lancia (1995) in South Carolina. Likewise, Greenberg (2001) suggested that increased light levels in wind-created canopy gaps positively influenced reptile abundance. However, increased prey availability is also likely to have a strong influence on the distribution and abundance of reptiles and amphibians. Most likely, a combination of factors such as increased prey availability, moisture, light and temperature contribute to their habitat choice.

Acknowlodgments-This research was supported by the National Research Initiatiwe Competitive Grants Program of the USDA Cooperative State Research Education and Extension Service (CSREES Grant No. 00-35101-9307). We thank the U.S. Forest Service-Savannah River and U.S. Department of Energy for access and logistical support throughout the duration of this project. Mention of product names does not constitute endorsement by the U.S. Government.

\section{LITERATURE CETED}

BEAUDRY, S., L. C. DUCALSNe AND B. CONE. 1997. Short-term effects of three forestry practices on carabid assemblages in a jack pine forest. Can f. For Res, 27:2065-2071. 
Bennett, S. H., J. W. Gibbons and J. Glanville. 1980. Terrestrial activity, abundance, and diversity of amphibians in differently managed forest types. Am. Midl. Nal., 103:412-4I6.

BLAKE, J G G AND W. G. Hoppes. 1986. Influence of resource abundance on use of treefall gaps by birds in an isolated woodlot. $A u k_{y}$ 103:328-340.

BrokAw, N. V. L. 1985. Gap-phase regeneration in a tropical forcst. Ecolog, 66:682-687.

BLEX, R. B. AND P. S. Cow. 1988. Douglas-fir forest in the Oregon and Washington Cascades: relation of the herpetofauna to stand age and moisture. $I m:$ R. C. Szaro, K. E. Sefverson and D. R. Patton (eds.). Management of amphibians, reptiles and small mammals in North America. USDA Forest Service, Gen. Tech. Rep. RM-166.

CLARK, R. D. 1974. Food habits of toads, genus Bufo (Amphibia: Bufonidae). Am. Midl Nat. 91:140-147. GLattereuck, W. K anp J. S. Measows. 1993. Regenerating oaks in the bottomlands. $/$ h. D. L. Loftis and C. E. MoGee (eds.). Oak regeneration: serious problems, practical recommendations. U.S. For. Serv. Gen. Tech. Rep. GTR SE-84.

ConnelL, J. H. 1978. Diversity in tropical rain forests and coral reefs. Sctence, 199:1802-1309.

Coscello, C. A. M. YAMmsaki, P. J. Pekins, W. B. Leak AND C. D. Nezrus. 2000 . Songbird response to group selection harvests and clearcuts in a New Hampshire nothern hardwood forests. For. Ecol. Manage, 127:41-54.

CROMER, R. B., J. D. LANHAM AND H. H. HANLFN. 2002. Herpetofaunal response to gap and skidder-rut wetland creation in a southern bottomland hardwood forest. For $\mathrm{Sci}, 48: 407-413$.

DAHL, T. E. 1990. Wetland losses in the United States 1780's to 1980's. U.S. Dept. of Interior, USFWS. Washington, D.C. $21 \mathrm{P}$

DENSLow, J. L. 1980. Gap partitioning among tropical rain forest trees. Biolrop., 12:47-55.

ENGE, K. M. ANo W. R. MAmos. 1986. Effects of clearcuting and site preparation on herpetofauna of a north Flonida flatwoods. For. Ecol. Manage, 14:177-192.

Fiwev, A. N. 1982. A treefrogs menu, selection for an evening's meal. Oerologir, 53:20-26.

GORHAM, L. E., B. D. KLELAND, S. MopptR, S. L. KING AND K. J. JoHnson. 1996. In: M. Flynn (ed.) Effects of canopy gap dynamics on arthropod abundance in a bottomland forest in northeast Arkansas. Procedings of the southern forested wetlands ecology and managcment conference. Clernson, South Carolina.

GREENBerG, C. H. 2001. Response of reptile and amphibian communities to canopy gaps created by wind disturbance in the southern Appalachians. For Ecol Manage, 148:135-144.

Guton, J. M. 1996. The role of uneven-aged silviculture in the context of ecosystern mariagement. Wes. J. App. For, 11:4-12.

Haber, V. R. 1926. The food of the Carolina tree frog, Hyla cinerea. $f$ Comp. Psych, 6(2),

HARTSHOR, G. S. 1978. Treefalls and tropical forest dynamics. $m$. P. B. Tomlinsor and M. H. Zimmerman (eds). Tropical forests as living systems. Cambridge University Press, Cambridge, England.

HELIOJA, J. M. KoTVLA AND J. NikmEla. 2001. Distribution of carabid beetles (Coleoptera, Carabidae) across a boreal forest clearcut ecotone. Cons. Biol, 15:370-377.

Holbrook, J. E. 1842. North American Herpetology, Vol. IV. Reprinted 1976 for The Society for the Study of Amphibians and Reptiles, Ithaca, Ncw York. I38 p.

Johnson, B. K AND J. L. CHuISTANSEN. 1976. The food and food habits of Blanchard's cricket frog, Acris crepitans blanchandi (Amphibia, Anura, Hylidae), in Iowa. J. Herpetol, 10:63-74.

KIIGo, J. C. 1997 . Establishment report: the gap project. USDA Forest Serwice, Savannah river Institute. $43 \mathrm{p}$.

K V. MrLL.rR AND W. P. SMITH. 1999. Effects of group-selection timber harvests in bottomland hardwoods on fall migrant birds. $J$. Field Omithol, 70:404-413.

KNOx, J. N. AND R. R. SHARTZ. 1990. Endangered, threatened, and rare vascular flora of the Savannah River Site. Savannah River Site National Environmental Research Park Program, Savannah River Ecology Lab, Aiken, SC, USA.

Konul, M., J. IJukronEN AND J. NIEmela. 2002. Boreal carabid beetle (Coleoptera: Carabidae) assemblages along the clearcut originated succession gradient. Bio. and Cons., 11:1269-1288.

KREBS, J. R. AND N. B. Davies. 1987. An introduction to behaviord ecology, 2nd ed. Sinauer Assoc., Sunderland, Massachusetts. 
LaBnNick, G. M. 1976. Prey availability, consumption and selection in the cricket frog, Acris creptitans. f. Herpetol, 10:299-998.

LEVEY, D. J. 1988. Tropical wet forest treefall gaps and distributions of understory binds and plants. Ecol, 69:1076-1079.

MaRTIN, T. E. AND J. R. KaRR. 1986. Patch utilization by migrating birds: resource oriented? Omis Scan., $17 \div 165-174$.

Moorman, C. E. AND D. C. GuYNN. 2001. Effects of group-selection opening size on breeding bird habitat use in a bottomland forest. Fcol Appl, 11:1680-I691.

OPLINGER, C. S. 1976 . Food habits and feeding activity of recently transformed and adult Hyla crucifer cucifer. Herpetol., 23:209-217.

PALLEY, E. F, B. S. CollINS AND W. P. SMITH. 1996. Early establishment of cherrybark oak in bottomland hardwood gaps: effects of seed predation, gap size, herbivory, and conpetition. $I n$ : K. M. Flynn (ed.). Proceedings of the southern forested wetlands ecology and mamagement conference. Clemson Uniw, Clenson, South Garolinia. $332 \mathrm{p}$.

PETRRNG, J. W. M. E. ELDRIDGE AND K. E. HALEY 1993. Effects of timber harvesting on southern Applachians salamanders. Cons. Biot, 7:369-370.

PHELPS, J. P. ANO R. A. LANCIA 1995. Effects of a clearcut on the herpetofauna of a South Carolina bottomland swamp. Brimly., 22:31-45.

Pougr., F. H., E. M. Smiti, D. H. RHones AND A. Colluzo. 1987. The abundance of salamanders in forest starids with different histories of disturbance. For Lol Manage, 20:1-9.

RuNkLE, J. R, 1998. Changes in southern Appalachian canopy tree gaps sampled thrice. Ecol, 79: $1768-1780$

Schemske, D. W. AND N. Brokaw. 1981. Treefalls and the distribution of understory birds in a tropical forest, Fcol, 62:938-945.

Siune, D. J. AND D. L. Phillips. 1991. Patch size of forest openings and arthropod populations. Oecologia, 86:325-394.

Sousa, W. P. 1984. The role of disturbance in natural communities. Ann. Rev. Ecol. Syst., 15-359-391.

THOMPSON, L. C. AND R. T. ALLEN. 1993. Site preparation affects ground beetles in a clearcut bottomland hardwood forest in southeastern Arkansas. In: J. C. Brissette (ed.). Proceedings of the seventh bieririal southern silvicultural research conference. Gen. Tech. Rep. SO-93. New Orleans, Louisiana.

TYLeR, J. D. AND R. D. HoEsteNBaCh. 1979. Differences in food of bullfrogs (Rana cateseiana) from pond and stream habitats in southwestern Oklahoma. S.W. Nat., 24:38-38.

Uril., G. AND P. G. MurPrfy. 1981. Composition, structure, and regeneration of tiera firme forest in the Amazon Besin of Venezuela. Trop. Ecol, 22:219-237.

USDA Folkst Sekvice. 1988. The South's fourth forest: alternatives for the future. U.S. For. Serv, For. Res. Rep. 24.

WALTERS, B. B. AND E. W. STRLES. 1996. Effect of canopy gaps and flower patch size on pollinator visitation. of Impatiens capensis. Bull. Torr. Bot., 123:184-188.

WALTZ, A M. AND T. G. WHFMAN. 1997. Plant development affects arthropod communities: opposing impacts of species removal. Ecology, 78:2133-2144.

WAREINER, M. D., T. E. NEbTker, T. D. Lfininger and J. S. Mradows. 2002. In: K W. Outcalt (ed.). Proceedings of the eleverth bieririal southerr silvicultural research conference. USDA Forest Service Gen. Tech. Rep. SRS-48.

WILSON, M. F. E. A. PERTER AND R. S. CoNDlT, 1982. Avian frugivore activity in relation to forest light gaps, Car. J. Sci, 18:1-6.

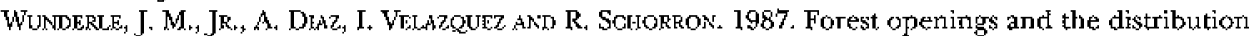
of understory birds in a Puerto Rican rainforest. Whils. Bull., 99:22-97. 